\title{
Assessing Stages of Readiness to Lose Weight among Overweight and Obese Adolescents using Trans-Theoretical Model
}

\author{
Asmah Johari ${ }^{1}$ and Rosnah Sutan ${ }^{1 *}$ \\ ${ }^{1}$ Department of Community Health Department, University of Kebangsaan Malaysia Medical Centre, Bandar Tun \\ Razak Cheras 56000 Kuala Lumpur Malaysia
}

Received: : December 21, 2016; Accepted: January 20, 2017; Published: February 01, 2017

*Corresponding author: Rosnah Sutan, Associate Professor, Community Health Department, Universiti Kebangsaan Malaysia Medical Centre, Bandar Tun Razak Cheras 56000 Kuala Lumpur Malaysia, Tel: +603-91455896 or 0193212256; Email: rosnah_sutan@yahoo.com; rosnah.sutan@ppukm.ukm.edu.my

\begin{abstract}
Introduction: Assessing the individual's level of readiness to change will help in losing weight and targeting for an ideal body weight. This study was aimed to determine the readiness to lose weight among overweight and obese adolescents using TransTheoretical Model (TTM) assessment tool.

Methods: A cross-sectional study was conducted among 631 adolescents aged 13 to 19 years whose screened as overweight or obese (body mass index for age with z-score of $\geq 1$ SD from WHO Reference 2007). Samples were selected using multistage random sampling from secondary level schools of two urban districts. The students had completed the translated and validated TTM constructs questionnaire and were categorized according to five stages of readiness to lose weight. One way ANOVA and MANOVA were used to analyze the relationship between stages of readiness to lose weight according to TTM assessment tool.
\end{abstract}

Results: Majority of the adolescents are in the action stage (40.3\%) followed by contemplation stage (26.5\%), preparation stage (15.5\%), maintenance $(11.4 \%)$ and the least in precontemplation stage $(6.3 \%)$. Significant differences across the stages of readiness to lose weight were identified in all processes of change, pros of decisional balance, physical activity and nutrition self-efficacy with $p<0.001$ and temptation of high-fat and high calorie foods $(\mathrm{F}=2.88$, $\mathrm{p}$ value $=0.022$ )

Conclusion: The significant differences found across the stages of readiness to lose weight using TTM model are useful in tailoring types of weight management interventions. Model

Keywords: Obesity; Weight loss; Adolescents; Tran-theoretical

\section{Introduction}

The prevalence of overweight and obesity among children and adolescents continuous to increase over the past 30 years has been recognized as a significant public health concern reported in many countries [1]. Scientifically, obesity has been associated with other diseases such as heart disease, hypertension, diabetes mellitus type II, and some types of cancer and sleep apnea [2]. Increasing trend of obesity incidence among children in the Asia-Pacific region has been reported in many studies [3-5]. In Malaysia, the national prevalence of children who were overweight was reported increasing from $5.4 \%$ in 2006 to $6.1 \%$ in 2011 [6].

Many studies have shown growing interest in applying the Trans-Theoretical Model (TTM) to both the treatment of obesity and its prevention through promoting healthy lifestyles in both the general population and at-risk groups [1]. The TTM provides a conceptual explanation of the processes that individuals need to undergo when modifying problem behaviors or acquiring positive behaviors. It focuses mainly in relation to changing dietary intake and physical activity, in order to achieve a sustainable weight loss. This model includes two levels: i) the Stages Of Change (SOC), which reflects the temporal dimension of the behavior as it been divided into five consecutive stages; and ii) a set of constructs that explain how people evolved along the SOC. The SOC are: the pre-contemplation (do not intend to lose their weight), contemplation (planning to lose their weight within 6 months), preparation (planning to lose their weight over next 30 days), action (have been making an effort by dieting and exercising to lose their weight for less than 6 months), or maintenance (had successfully maintained their desired weight for more than 6 months) [7]. The other four additional TTM constructs are the Processes Of Change (POC), decisional balance, self-efficacy and temptation [7]. POC is a process or strategy that individual engage in attempt to lose weight that related to behavioral or experiential strategies. TTM generally proposes steps in POC to promote health behavior change which is categorized into i) experiential processes: consciousness raising, counter conditioning, dramatic relief, environmental re-evaluation, reinforcement management and ii) behavioral processes: self-liberation, self-reevaluation, social liberation, helping relationships, and stimulus control [8]. The model predicts that experiential processes increased in the contemplation stage whereas behavioral processes increased 
more during maintenance $[9,10]$. Decisional balance, measures the balance between the benefits and the barriers of change. The individuals who were in pre-contemplation stage reported least benefits of changing behavior compared to those in the action and maintenance stages $[7,8]$. Self-efficacy is measured based on one's belief in their ability to produce something to achieve their desire needs [11]. In regards with weight loss, self-efficacy promotes weight management through exercise and physical activity $[12,13]$. When the counseling or the intervention targeted according to stages of readiness to change (compared with usual care), the respondents were more likely to change their diet and their physical activity $[14,15]$. By understanding the process of change faced by the targeted group, the intervention initiated will be more effectively accepted. Hence, this study is conducted to assess the readiness to lose weight among overweight and obese adolescents using the TTM targeting among the adolescent group.

\section{Methods}

\section{Sample and procedures}

A cross sectional study was conducted from Mac to November 2014 in six secondary schools from urban setting districts in Negeri Sembilan Malaysia. The respondents were selected by multistage random sampling. Students from the randomly selected six schools were screened for BMI according to World Health Organization (WHO) reference for age and gender [16]. A total of 2281 students aged 13 to 19 years old were screened and about 631 overweight and obese students of which their Body Mass Index (BMI) for age with z-score of $\geq 1$ SD from WHO Reference 2007 were recruited in this study. Information about the study was delivered to each respondent and the consent was taken from parent before data collection conducted. Only students with parental approval and willing to participate in this study were given questionnaires. The data was collected during extra-curricular activities which not affecting their education schedule.

\section{Anthropometric measurements}

Anthropometric measurements were taken for body weight in kilograms and height in meters. Body weight was measured using Tanita digital weighing scale with an accuracy of $0.1 \mathrm{~kg}$. The students were asked to wear school uniforms and socks when they were weighted. The height was measured using SECA stadiometer and recorded to the nearest to $0.1 \mathrm{~cm}$. BMIfor-age by gender specific was calculated using WHO AnthroPlus software version 1.0.2 [16].

\section{Instruments measuring TTM constructs}

All psychosocial constructs of TTM scales were translated to Malay language by two English teachers with more than 10 years experienced. Any discrepancies between the two versions of translation were clarified by the researchers in a discussion for agreement. Test retests were conducted among 15 students at a non-participatory school. A pilot study was conducted on 267 secondary school students aged 13-19 years old which is based on the ratio of five students per item [17]. The validity and reliability of the questionnaire were tested on the 48 items related to process of change for weight control scale (POC) [18]. The Kaiser-Meyer-Olkin value of 0.907 and significant Bartlett's Test of sphericity with $\mathrm{p}$ value $<0.001$ proved the adequacy of measurement data [19]. The number of factors or components of the instrument was determined by Eigen value of more than one [20,21]. All items in excess of the value factor of 0:32 were retained for analysis. Summary of the instrument reliability and validity is showed on Table 1.

\section{Stages of readiness to lose weight}

The measurement was based on the scale for stages of change (The S-Weight). It was developed to assess the readiness to lose weight for overweight and obese individual [22]. It consists of five options that are mutually exclusive, among which respondents had to choose in order to be allocated to one of the five stages of change.

\section{Processes of change (POC)}

A process of change instrument originally consists of 48 items with 12 factors [18]. Each item was scored on a Likert scale with scale of one for 'never' to five for 'always'. This scale was adapted and has been tested in study among adolescents in South Korea [23] which showed good Cronbach alpha $(\alpha)$ coefficients between $0: 57$ to 0.86 .

\section{Decisional Balance}

This validated scale was developed by O'Connell \& Velicer [24] in 1988. It consists of 20 Likert scale items, 10 items for pro (even numbered item) and 10 items for cons (odd-numbered items). Items scored from one for 'Not important at all' to five for 'Very Important'.

\section{Physical Activity and Nutrition Self-Efficacy}

Self-efficacy is measured using a scale that was adapted and modified from Physical Activity and Nutrition Self Efficacy (PANSE), consisting of 11 Liked-scale items [25]. The original scale consists of diet (8 items) and physical activities (3 items) that affect weight loss. In this study, some items have been modified to suit the study population of adolescents. Answers choices are summed to obtain the self-efficacy score and total score were ranged from 11 to 99.

\section{The temptation to eat foods that are high in fat and high in calories}

Scale was adapted from 'Situational Temptations Questionnaire for Adolescents' by Rossi et al. [26]. It consists of nine items. Students were asked on how tempted they were to eat foods high fat and high calories in difficult situation. A Likert scale was range from one for 'Not at all tempted' to five 'Extremely tempted'.

\section{Data Analysis}

Data were analyzed using SPSS (Statistical Package for the Social Sciences) version 20.0. Univariate analysis using one-way ANOVA for continuous data and multivariate analyses of variance (MANOVA) were used to determine the differences between 
Table 1: Summary of reliability and validity of Malay's version TTM constructs instruments.

\begin{tabular}{|c|c|c|c|c|c|}
\hline \multicolumn{2}{|r|}{$\begin{array}{c}\text { Instruments } \\
\text { (Numbers of items) }\end{array}$} & $\begin{array}{c}\text { Cronbach's } \\
\alpha\end{array}$ & $\begin{array}{l}\text { Intra-class correlation } \\
\qquad(95 \% \mathrm{CI})\end{array}$ & $\begin{array}{l}\text { Corrected total } \\
\text { item correlation }\end{array}$ & $\begin{array}{l}\text { Factor loading } \\
\text { (PCA) }\end{array}$ \\
\hline \multicolumn{6}{|c|}{ Processes of change(39) } \\
\hline 1. & Conscious Raising(4) & 0.705 & $0.67(0.63-0.71)$ & $0.30-0.61$ & $0.41-0.64$ \\
\hline 2. & Counter conditioning(3) & 0.604 & $0.57(0.52-0.62)$ & $0.32-0.49$ & $0.46-0.76$ \\
\hline 3. & Dramatic control(5) & 0.789 & $0.78(0.75-0.80)$ & $0.49-0.63$ & $0.45-0.71$ \\
\hline 4. & Environmental re-evaluation(5) & 0.767 & $0.76(0.72-0.79)$ & $0.49-0.59$ & $0.38-0.67$ \\
\hline 5. & Helping relationship(4) & 0.795 & $0.79(0.77-0.82)$ & $0.41-0.70$ & $0.47-0.78$ \\
\hline 6. & Reinforce management(4) & 0.733 & $0.69(0.65-0.730$ & $0.51-0.54$ & $0.44-0.76$ \\
\hline 7. & Self-liberation(6) & 0.812 & $0.78(0.75-0.81)$ & $0.49-0.65$ & $0.54-0.72$ \\
\hline 8. & Social liberation(3) & 0.595 & $0.54(0.48-0.600$ & $0.32-0.47$ & $0.48-0.70$ \\
\hline 9. & Stimulus control(5) & 0.79 & $0.76(0.73-0.79)$ & $0.51-0.61$ & $0.51-0.74$ \\
\hline \multicolumn{6}{|c|}{ Decisional Balance (20) } \\
\hline 1 & Pros $(10)$ & 0.902 & $0.88(0.86-0.90)$ & $0.58-0.76$ & $0.64-0.80$ \\
\hline 2 & Cons $(10)$ & 0.739 & $0.72(0.70-0.78)$ & $0.22-0.59$ & $0.38-0.65$ \\
\hline \multicolumn{2}{|c|}{ Physical Activity and Nutrition Self-efficacy (11) } & 0.908 & $0.86(0.85-0.92)$ & $0.51-0.73$ & $0.49-0.86$ \\
\hline \multicolumn{2}{|c|}{$\begin{array}{l}\text { Situational Temptations Questionnaire for } \\
\text { Adolescents(9) }\end{array}$} & 0.837 & $0.82(0.78-0.85)$ & $0.49-0.61$ & $0.75-0.88$ \\
\hline
\end{tabular}

stages of readiness to lose weight and other TTM constructs that act as dependent variables. The significant value is taken at $p<$ 0.05

\section{Results}

Majority of the adolescents are in the action stage (40.3\%) followed by contemplation stage $(26.5 \%)$, preparation stage (15.5\%), maintenance $(11.4 \%)$ and the least was the precontemplation stage (6.3\%). Univariate analysis using One-way ANOVA was used to determine the relationship between stages of readiness to lose weight and other TTM constructs. Table 2 shows the distribution of mean and Standard Deviation (SD) for the TTM constructs across the stages of readiness to lose weight. All domains in the process of change (POC), physical activity and nutrition self-efficacy and the pros component of decisional balance showed with $\mathrm{p}$ value of $<0.001$. Other variables on temptation for high-fat foods and high calories were also shown significant relationship with the stages of readiness of lose weight ( $F=2.88$, $p$ value $=0.022$ ). Turkey post-hoc tests found that mean score for all the domains in the process of change are significantly lower at pre-contemplation compared to other stages. Table 2 showed a significant relationships between stages of readiness to lose weight and pros component of decisional balance $(\mathrm{F}=10.62$, $p=<0.001)$. However, the cons component of decisional balance revealed no significant relationship $(\mathrm{F}=1.29, \mathrm{p}=0.271)$. Posthoc tests also found that students in pre-contemplation were significantly had lower mean scores of pros component compared to other four stages of readiness to lose weight. Statistically significant relationship was found between self-efficacy for physical activity and nutrition and stages of readiness to lose weight. The post-hoc tests showed that, for those who at precontemplation, contemplation and preparation had significant lower mean scores than those at action and maintenance stage of readiness to lose weight. The temptation of foods high in fat and high in calories also significantly correlated with the stages of readiness to lose weight with post-hoc tests revealed that only those who were at the pre-contemplation had significant lower mean scores than with those at action and maintenance stages. MANOVA was used to test the relationship between the five stages of readiness to lose weight and the TTM constructs. This multivariate model (Wilks' Lambda) was significant, ( $\mathrm{F}=4.514, p$ $<0.001$ ).

\section{Discussion}

Two fifth of overweight and obese adolescents in the sample population of secondary schools in urban setting districts were at action stage of readiness to lose weight. Being an overweight or obese pose the adolescent at greater risk to their health status have been found in earlier studies that contributing to higher level of readiness to change $[27,28]$. Significant differences of mean scores was noted for the process of change, the decisional balance, the self-efficacy and the temptations for high-fat foods and high calories in this study. The pattern was similarly found in earlier studies done in developed countries. It proved that the progression of the stages of readiness to lose weight is related to TTM constructs [29]. Mean scores of all processes of change is lowest among overweight and obese students at precontemplation and increased across the stages of readiness to lose weight and climaxes in the action before declining again in the maintenance [8]. Although all levels of process of change 
Table 2: The relationship between readiness to lose weight and other TTM constructs. Stages of readiness to lose weight $(n=631)$

Variable

\begin{tabular}{|c|c|c|c|c|}
\hline \multicolumn{5}{|c|}{ Stages of readiness to lose weight (n= 631) } \\
\hline PC (f= 40) & C (f=167) & PR (f= 98) & A (f= 254) & M (f= 72) \\
\hline $\begin{array}{c}\text { mean } \\
\text { (sd) }\end{array}$ & $\begin{array}{c}\text { mean } \\
\text { (sd) }\end{array}$ & $\begin{array}{c}\text { mean } \\
\text { (sd) }\end{array}$ & $\begin{array}{c}\text { mean } \\
(\text { sd) }\end{array}$ & $\begin{array}{c}\text { mean } \\
\text { (sd) }\end{array}$ \\
\hline
\end{tabular}

Processes of change to lose weight

\begin{tabular}{|c|c|c|c|c|c|c|c|c|}
\hline $\begin{array}{l}\text { Consciousness } \\
\text { Raising }\end{array}$ & $\begin{array}{c}8.37 \\
(3.01)\end{array}$ & $\begin{array}{l}10.56 \\
(3.28)\end{array}$ & $\begin{array}{l}11.56 \\
(3.37)\end{array}$ & $\begin{array}{l}12.44 \\
(3.52)\end{array}$ & $\begin{array}{l}11.46 \\
(3.48)\end{array}$ & 16.32 & $\begin{array}{c}< \\
0.001^{*}\end{array}$ & $\mathrm{PC}<\mathrm{C}, \mathrm{PR}, \mathrm{A} \& \mathrm{M}, \mathrm{C}<\mathrm{A}$ \\
\hline $\begin{array}{c}\text { Counter } \\
\text { Conditioning }\end{array}$ & $\begin{array}{c}6.60 \\
(2.23)\end{array}$ & $\begin{array}{c}7.84 \\
(2.37)\end{array}$ & $\begin{array}{c}8.52 \\
(2.40)\end{array}$ & $\begin{array}{c}9.49 \\
(2.49)\end{array}$ & $\begin{array}{c}9.64 \\
(2.39)\end{array}$ & 22.31 & $0.001^{<}$ & $\begin{array}{c}\mathrm{PC}<\mathrm{C}, \mathrm{PR}, \mathrm{A} \& \mathrm{M}, \mathrm{C}<\mathrm{A} \& \mathrm{M}, \\
\mathrm{PR}<\mathrm{A} \& \mathrm{M}\end{array}$ \\
\hline $\begin{array}{c}\text { Dramatic } \\
\text { control }\end{array}$ & $\begin{array}{l}11.53 \\
(4.67)\end{array}$ & $\begin{array}{l}13.87 \\
(4.84)\end{array}$ & $\begin{array}{l}14.65 \\
(5.18)\end{array}$ & $\begin{array}{l}15.81 \\
(4.91)\end{array}$ & $\begin{array}{l}13.88 \\
(5.46)\end{array}$ & 8.86 & $0.001^{*}$ & $\begin{array}{c}\mathrm{PC}<\mathrm{PR} \& \mathrm{~A}, \mathrm{C}<\mathrm{A}, \\
\mathrm{AX}<\mathrm{M}\end{array}$ \\
\hline $\begin{array}{c}\text { Environmental } \\
\text { reevaluation }\end{array}$ & $\begin{array}{c}8.05 \\
(3.53)\end{array}$ & $\begin{array}{c}9.32 \\
(3.86)\end{array}$ & $\begin{array}{l}10.37 \\
(3.68)\end{array}$ & $\begin{array}{l}10.48 \\
(3.96)\end{array}$ & $\begin{array}{l}10.54 \\
(3.77)\end{array}$ & 5.44 & $\begin{array}{c}< \\
0.001^{*}\end{array}$ & $\begin{array}{c}\mathrm{PC}<\mathrm{PR}, \mathrm{A} \& \mathrm{M}, \\
\mathrm{C}<\mathrm{A}\end{array}$ \\
\hline $\begin{array}{c}\text { Helping } \\
\text { relationship }\end{array}$ & $\begin{array}{c}7.68 \\
(3.04)\end{array}$ & $\begin{array}{c}9.23 \\
(3.57)\end{array}$ & $\begin{array}{l}10.63 \\
(3.94)\end{array}$ & $\begin{array}{l}10.43 \\
(4.13)\end{array}$ & $\begin{array}{l}10.79 \\
(4.02)\end{array}$ & 7.39 & $<0.001^{*}$ & $\begin{array}{c}\mathrm{PC}<\mathrm{PR}, \mathrm{A} \& \mathrm{M} \\
\mathrm{C}<\mathrm{PR}, \mathrm{A} \& \mathrm{M}\end{array}$ \\
\hline $\begin{array}{c}\text { Reinforce } \\
\text { management }\end{array}$ & $\begin{array}{c}6.85 \\
(3.00)\end{array}$ & $\begin{array}{c}7.48 \\
(3.47)\end{array}$ & $\begin{array}{c}8.73 \\
(3.96)\end{array}$ & $\begin{array}{c}8.78 \\
(3.78)\end{array}$ & $\begin{array}{c}8.59 \\
(3.81)\end{array}$ & 5.13 & $<0.001^{*}$ & $\mathrm{PR}<\mathrm{A}, \mathrm{C}<\mathrm{A}$ \\
\hline Self-liberation & $\begin{array}{l}15.55 \\
(5.87)\end{array}$ & $\begin{array}{l}19.20 \\
(5.07)\end{array}$ & $\begin{array}{l}20.49 \\
(5.04)\end{array}$ & $\begin{array}{l}22.71 \\
(5.03)\end{array}$ & $\begin{array}{l}21.31 \\
(5.39)\end{array}$ & 23.50 & $<0.001^{*}$ & $\begin{array}{r}\mathrm{PC}<\mathrm{C}, \mathrm{PR}, \mathrm{A} \& \mathrm{M}, \mathrm{C}<\mathrm{A} \& \mathrm{M} \\
\mathrm{PR}<\mathrm{A}\end{array}$ \\
\hline $\begin{array}{c}\text { Social } \\
\text { liberation }\end{array}$ & $\begin{array}{c}8.40 \\
(3.37)\end{array}$ & $\begin{array}{l}10.22 \\
(2.95)\end{array}$ & $\begin{array}{l}10.60 \\
(2.65)\end{array}$ & $\begin{array}{l}11.03 \\
(2.78)\end{array}$ & $\begin{array}{l}10.28 \\
(3.00)\end{array}$ & 8.01 & $<0.001^{*}$ & $\begin{array}{c}\mathrm{PC}<\mathrm{C}, \mathrm{PR}, \mathrm{A} \& \mathrm{M} \\
\mathrm{C}<\mathrm{A}\end{array}$ \\
\hline $\begin{array}{c}\text { Stimulus } \\
\text { control }\end{array}$ & $\begin{array}{c}7.90 \\
(3.82)\end{array}$ & $\begin{array}{c}9.58 \\
(3.82)\end{array}$ & $\begin{array}{l}11.11 \\
(4.13)\end{array}$ & $\begin{array}{l}11.67 \\
(4.55)\end{array}$ & $\begin{array}{l}11.18 \\
(4.88)\end{array}$ & 10.79 & $\begin{array}{c}< \\
0.001^{*}\end{array}$ & $\mathrm{PC}<\mathrm{PR}, \mathrm{A} \& \mathrm{M}, \mathrm{C}<\mathrm{PR} \& \mathrm{~A}$ \\
\hline
\end{tabular}

Decisional Balance to lose weight

\begin{tabular}{|c|c|c|c|c|c|c|c|c|}
\hline Pros & $\begin{array}{l}31.10 \\
(11.32)\end{array}$ & $\begin{array}{l}38.16 \\
(9.21)\end{array}$ & $\begin{array}{l}38.47 \\
(8.08)\end{array}$ & $\begin{array}{l}40.43 \\
(8.00)\end{array}$ & $\begin{array}{l}39.38 \\
(8.25)\end{array}$ & 10.62 & $<0.001^{*}$ & $\mathrm{PC}<\mathrm{PR}, \mathrm{A} \& \mathrm{M}$ \\
\hline Cons & $\begin{array}{l}26.18 \\
(7.82)\end{array}$ & $\begin{array}{l}27.04 \\
(6.26)\end{array}$ & $\begin{array}{l}26.71 \\
(6.67)\end{array}$ & $\begin{array}{l}26.03 \\
(6.53)\end{array}$ & $\begin{array}{l}25.15 \\
(6.36)\end{array}$ & 1.29 & 0.271 & - \\
\hline $\begin{array}{l}\text { Physical } \\
\text { Activity and } \\
\text { Nutrition Self- } \\
\text { efficacy }\end{array}$ & $\begin{array}{l}41.75 \\
(18.40)\end{array}$ & $\begin{array}{c}46.14 \\
(13.95)\end{array}$ & $\begin{array}{c}47.85 \\
(13.54)\end{array}$ & $\begin{array}{c}55.72 \\
(15.79)\end{array}$ & $\begin{array}{l}57.90 \\
(15.95)\end{array}$ & 18.80 & $<0.001^{*}$ & $\begin{array}{c}\mathrm{PC}<\mathrm{A} \& \mathrm{M}, \mathrm{C}<\mathrm{A} \& \mathrm{M}, \\
\mathrm{PR}<\mathrm{A} \& \mathrm{M}\end{array}$ \\
\hline $\begin{array}{l}\text { Temptation for } \\
\text { high fat and } \\
\text { calories diet }\end{array}$ & $\begin{array}{l}27.23 \\
(8.58)\end{array}$ & $\begin{array}{l}24.93 \\
(6.68)\end{array}$ & $\begin{array}{l}24.48 \\
(5.36)\end{array}$ & $\begin{array}{l}24.05 \\
(5.98)\end{array}$ & $\begin{array}{l}23.44 \\
(6.42)\end{array}$ & 2.88 & $0.022^{* *}$ & $\mathrm{PC}<\mathrm{A} \& \mathrm{M}$ \\
\hline \multicolumn{9}{|c|}{$\begin{array}{l}\text { One way ANOVA } \\
\mathrm{sd}=\text { Standard deviation } \\
\mathrm{PC}=\text { Pre-contemplation, } \mathrm{C}=\text { Contemplation, } \mathrm{PR}=\text { Preparation, } \mathrm{A}=\text { Action, } \mathrm{M}=\text { Maintanence } \\
* \text { Significant if } \mathrm{P} \text { value }<0.05\end{array}$} \\
\hline
\end{tabular}

showed significant relationship with readiness to lose weight among overweight and obese adolescent, stronger association were reported for self-liberation, counter conditioning and conscious raising $[18,23]$. This study supports earlier findings that the process of change especially self-liberation and counter conditioning change frequently in the late stages of readiness to change [30].

Decisional Balance construct is the precedence between the positive or negative reasons for someone to improve 
the problematic behavior. The mean scores of pros among overweight and obese students were lowest among those at pre-contemplation, and noted to increase across the stages of readiness to lose weight and culminated at maintenance $[23,24]$. Those at pre-contemplation significantly having lower mean scores of pros than those at preparation, action and maintenance stages which indicated that they had more reasons and having less positive reasons for change [31].

Finding showed that self-efficacy increases significantly as they progress through the stages of change [18]. Physical activity and nutrition self-efficacy positively affect weight loss in different populations [32-34]. Temptation and self-efficacy have an inverse relationship with one another across stages of change. The temptation stage is highest during the earlier stages of change and lowest during the later stages was noted as well in other studies $[8,26,35,36]$.

The limitations of present study are the age of respondents (13-19 years) was covered only for middle adolescent group that do not represent the overall adolescents. Using the selfadministrated questionnaire may influence the adolescent response. Significant differences of the TTM constructs across the stages of readiness to lose weight will give input for effective weight management interventions. A follow-up study in the future should be conducted to strengthen the intervention measure in order to increase the healthy lifestyle practice among overweight and obese adolescents.

\section{Acknowledgement}

The funding for the study come from the Ethical Committee Universiti Kebangsaan Malaysia Medical Centre.

\section{References}

1. Ogden CL, Carroll MD, Curtin LR, Lamb MM, Flegal KM. Prevalence of high body mass index in US children and adolescents, 2007-2008. JAMA. 2010;303(3):242-9. doi: 10.1001/jama.2009.2012.

2. World Health Organisation. Obesity: preventing and managing the global epidemic. Report of a WHO consultation. World Health Organ Tech Rep Ser. 2000;894:1-253.

3. Langendijk G, Wellings S, van Wyk M, Thompson SJ, McComb J Chusilp K. The prevalence of childhood obesity in primary school children in urban Khon Kaen, northeast Thailand. Asia Pac J Clin Nutr. 2003;12(1):66-72.

4. Sabanayagam C, Shankar A, Chong YS, Wong TY, Saw SM. Breastfeeding and overweight in Singapore school children. Pediatr Int. 2009;51(5):650-6. doi: 10.1111/j.1442-200X.2009.02919.x.

5. Ji CY, Cheng TO. Epidemic increase in overweight and obesity in Chinese children from 1985 to 2005. Int J Cardiol. 2009;132(1):1-10. doi: 10.1016/j.ijcard.2008.07.003.

6. Institute of Public Health. The National Health and Morbidity Survey 2011(NHMS 2011): Kuala Lumpur, Malaysia: Institute for Public Health, Ministry of Health Malaysia. 2011;188p.

7. Prochaska JO, Velicer WF, Rossi JS, Goldstein MG, Marcus BH, Rakowski W, et al. Stages of change and decisional balance for 12 problem behaviors. Health Psychology. 1994;13(1):39-46.

8. Velicer WF, Prochaska JO, Fava JL, Norman GJ, Redding CA. Smoking cessation and stress management: Applications of the Transtheoretical Model of behavior change. Homeostasis. 1998;38:216-233.

9. DiClemente CC, Prochaska JO, Fairhurst SK, Velicer WF, Velasquez MM, Rossi J.S. The process of smoking cessation: an analysis of precontemplation, contemplation and preparation stages of change. Journal of Consulting and Clinical Psychology. 1991;59:295-304.

10. Prochaska JO, DiClemente CC. Stages and processes of self-change of smoking: Toward an integrative model of change. J Consult Clin Psychol. 1983;51(3):390-5.

11. Bandura A. Health promotion by social cognitive means. Health Educ Behav. 2004;31(2):143-64.

12. Simonavice EM, Wiggins MS. Exercise barriers, self-efficacy, and stages of change. Percept Mot Skills. 2008;107(3):946-50.

13. Thunfors P, Collins BN, Hanlon AL. Health behavior interests of adolescents with unhealthy diet and exercise: implications for weight management. Health Educ Res. 2009;24(4):634-45. doi: 10.1093/her/ cyn064.

14. Berg-Smith S, Stevens VJ, Brown KM, Van Horn L, Gernhofer N, Peters E, et al. A brief motivational intervention to improve dietary adherence in adolescents. The Dietary Intervention Study in Children (DISC) Research Group. Health Educ Res. 1999;14(3):399-410.

15. Steptoe A, Kerry S, Rink E. Hilton S. The impact of behavioral counseling on stage of change in fat intake, physical activity, and cigarette smoking in adults at increased risk of coronary heart disease. Am J Public Health. 2001;91(2):265-9.

16. World Health Organization. 2009. AnthroPlus for personal computers Manual: Software for assessing growth of the world's children and adolescents. Geneva: WHO, (http://www.who.int/growthref/tools/ en/ ).

17. MacCallum RC, Widaman KF, Preacher KJ, Hong S. Sample size in factor analysis: The role of model error. Multivariate Behav Res. 2001;36(4):611-37. doi: 10.1207/S15327906MBR3604_06.

18. Prochaska JO, Norcross JC, Fowler JL, Follick MJ, Abrams DB. Attendance and outcome in a work-site weight control program: processes and stages of change as process and predictor variables. Addict Behav. 1992;17(1):35-45.

19. Field A. Discovering statistics using IBM SPSS Statistics. Fourth Edition. 2013; Sage Publication: London.

20. De Von HA, Block ME, Moyle-Wright P, Ernst DM, Hayden SJ, Lazzara DJ, et al. A psychometric Toolbox for testing Validity and Reliability. J Nurs Scholarsh. 2007;39(2):155-64.

21. Tabachnick BG, Fidell LS. Using multivariate statistics, 6th ed. Boston: Pearson. 2013.

22. Andrés A, Saldaña C, Gomez-Benito J. Establishing the stages and processes of change for weight Loss by consensus of experts. Obesity (Silver Spring). 2009;17(9):1717-23. doi: 10.1038/oby.2009.100.

23. Chae S-M, Kwon I, Kim C-J, Jang J. Analysis of Weight Control in Korean Adolescents Using the Trans theoretical Model. Western Journal of Nursing Research. 2010;32(4):511-529.

24. O'Connell D, Velicer WF. A decisional balance measure and the stages of change model for weight loss. Int J Addict. 1988;23(7):729-50.

25. Latimer L, Walker LO, Kim S, Pasch KE, Sterling BS. Self-efficacy Scale for Weight Loss among Multi-ethnic Women of Lower Income: A Psychometric Evaluation. J Nutr Educ Behav. 2011;43(4):279-83. doi: 10.1016/j.jneb.2010.09.007. 
26. Rossi SR, Greene GW, Rossi JS, Plummer BA, Benisovich SV, Keller S, et al. 2001. Validation of decisional balance and situational temptations measures for dietary fat reduction in a large school-based population of adolescents. Eat Behav. 2001 spring;2(1):1-18.

27. Wee CC, Davis RB, Phillips RS. Stage of readiness to control weight and adopt weight control behaviors in primary care. J Gen Intern Med. 2005;20(5):410-5.

28. Hintze LJ, Cattai GBP, da Silva DF, Junior NN. Stage of readiness to change of behavior in adolescents interested in joining the Multi professional Obesity Treatment Program. Rev Paul Pediatr. 2012;30(2):237-43.

29.Guo B, Aveyard P, Fielding A, Sutton S. Do the Transtheoretical Model processes of change, decisional balance and temptation predict stage movement? Evidence from smoking cessation in adolescents. Addiction. 2009;104(5):828-38. doi: 10.1111/j.13600443.2009.02519.x.

30. Di Noia J, Thompson D. Processes of change for increasing fruit and vegetable consumption among economically disadvantaged African American adolescents. Eat Behav. 2012;13(1):58-61. doi: 10.1016/j. eatbeh.2011.10.001.
31. Redding CA, Rossi JS, Rossi SR, Velicer WF, Prochaska JO. Health behavior models. The International Electronic Journal of Health Education. 2000;3:180-193.

32. Richman RM. Loughnan GT, Droulers AM, Steinbeck KS, Caterson ID. Self-efficacy in relation to eating behaviour among obese and nonobese women. Int J Obes Relat Metab Disord. 2001;25(6):907-13.

33. Roach JB, Yadrick MK, Johnson JT, Boudreaux LJ, Forsythe WA, Billon W. Using self-efficacy to predict weight loss among young adults. J Am Diet Assoc. 2003;103(10):1357-9.

34. Krummel DA, Semmens E, Boury J, Gordon PM, Larkin KT. Stages of change for weight management in postpartum women. J Am Diet Assoc. 2004;104(7):1102-8.

35. Prochaska JO, Velicer WF. The transtheoretical model of health behaviour change. Am J Health Promot. 1997;12(1):38-48.

36. Fallon EA, Hausenblas HA, Nigg CR. The transtheoretical model and exercise adherence: Examining construct associations in later stages of change. Psychology of Sport and Exercise. 2005;6(6):629-641. 